\title{
Waar lê die wortels van die "sondige verskeurdheid" in die Kontrovers Bosman-Goddefroy 1888-1890?
}

\section{S J BOTHA}

Die kontrovers Bosman-Goddefroy het deel gevorm van 'n breër twisgeskryf in die openbare pers tussen die jare 1888-1890 oor die sogenaamde kerkkwessie en moet gesien word teen die agtergrond van die mislukte kerkvereniging van 1885 . Die verhewe en idealistiese verwagting van kerklike eenheid as uitvloeisel en bekroning van die nasionale eenheidsgevoel, wat na die anneksasie van die Zuid-Afrikaansche Republiek deur Engeland in 1877 sterk onder die Hollands-Afrikaanse ingesetenes na vore gekom het, het nie gerealiseer nie. Nie alleen het slegs twee van die drie Hollands-Afrikaanse kerke $^{1}$ vanaf 1882 aan die onderhandelings insake kerkvereniging deelgeneem nie, maar spoedig na die deurvoering van die vereniging deur die Algemene Kerkvergaderings van die twee deelnemende kerke. ${ }^{2}$ die Nederduitsch Hervormde en Nederduitse Gereformeerde kerke, het dit geblyk dat die vereniging nie geslaagd was nie en dat die verdeeldheid en twis op kerklike erf eens so erg sou wees. 'n Baie groot deel van die lidmate van die Nederduitsch Hervormde Kerk het die optrede van die Algemene Kerkvergadering, om die Nederduitsch Hervormde Kerk op te hef en tot die verenigde kerk toe te tree, as onwettig verwerp en verkies om buite die vereniging te bly en liefs hulle kerk te handhaaf. ${ }^{3}$ 'n Verdere groot deel van die Nederduitsch Hervormde Kerk se lidmate wat wel met die vereniging meegegaan het, het spoedig om verskeie redes ${ }^{4}$ so ontnugter geraak met die verenigde kerk dat hulle hulle dadelik onttrek het of hulle gereed gemaak het om by 'n geskikte geleentheid te onttrek en terug te keer na die Nederduitsch Hervormde Kerk. ${ }^{5}$

Indien die gesindheid van die twee kerke voor die kerkvereniging teenoor mekaar nie altyd na wens was nie, het dit na die kerkvereniging beslis 'n laagtepunt bereik. Die verdeeldheid was groter as ooit en die bitterheid skerper. Dit is te begrype, hoewel nie goed te keur nie, dat in die gelaaide atmosfeer na die mislukking, bitter woorde, verwyte en beskuldigings oor en weer geslinger sou word en dat van 'n nugtere, en kalme debat, veral in die dagbladpers, nie veel tereg sou kom nie. In elk geval sou dit allermins die vereniging kon red. Die hele koerante-getwis uit die tyd maak 'n uiters treurige indruk.

"Dit was gewoonlik van weerskante van 'n haatlike en persoonlike aard sonder die minste christelike gees. ${ }^{6}$ 
Van die predikante van die verenigde kerk was die veral H S Bosman van Pretoria en $\mathrm{H}$ L Neethling van Utrecht wat aan die geskryf deelgeneem het. Van die kant van die Nederduitsch Hervormde Kerk het veral ouderling C J J Joubert gereageer. ${ }^{7}$ Die enigste predikant van die Nederduitsch Hervormde Kerk, ds M J Goddefroy, het ten ene male geweier om ook aan die koerantegeskryf deel te neem. Hy het in beginsel beswaar gehad daarteen dat so'n netelige saak soos die kerkkwessie in die dagbladpers bespreek word. Sy onomwonde en duidelike standpunt was: ${ }^{8}$

". . omdat theologische geschilpunten in een Volksblad niet thuis hooren; daarin niet naar behooren genoegzaam kunnen besproken worden; en bij oppervlakkige bespreking gewoonlijk uitloopen op stofwolken, waarin men zich hult; terwijl de partijen al sterker en vaster tegenover elkander gaan staan; en ten slotte ieder zich zelf gelukwenscht met de grootsche overwinning op den tegenstanders behaald."

Slegs by een geleentheid het Goddefroy wel 'n enkele brief in sake die aangeleentheid in ' $n$ dagblad laat verskyn. Dit was ' $n$ brief gedateer 12 Maart 1889 in die Volkstem van 18 Maart, waarin hy 'n openbare verklaring afgelê het ten opsigte van die aanvalle, beskuldigings en bewerings van $\mathrm{H} S$ Bosman teen die Nederduitsch Hervormde Kerk en hom as persoon soos vervat was in die sewe stukke van Bosman wat tussen 7 Januarie en 7 Februarie 1889 onder die titel "De Leerkwestie" in die Volkstem verskyn het. Goddefroy se genoemde brief was nie 'n antwoord of verweer op Bosman se skrywes nie, maar'n openbare verklaring omdat hy hom beswaard gevoel het vanweë Bosman se "verdachtmakend twistgeschrijf" en omdat die stukke van Bosman geskryf is "in een toon en geest die bij ieder weldenkende afkeer verwekt." Daarom het hy hom verplig gevoel om in die openbaar te verklaar:

"dat hij geen notitie meer zal nemen van het geschrijf des heeren Bosman, ook al gelieft het dezen nog schandelijker verdichtselen en personaliteiten aan den man te brengen en op zijn naam te stellen; en dat wel om de navolgende redenen;

1) Omdat hij hoegenaamd geen deel wil hebben aan een bedrijf, dat hem onchristelijk, onstichtilijk en den Evangeliedienaar onwaardig voorkomt.

2) Omdat hij geen kans ziet met hoop op goeden uitslag, te discusieeren met "iemand, die geen onderscheid maakt tussen "Leerkwestie" en Godsdienst, en op de verklaring, dat men over Leerkwesties niet in een volksblad wil schrijven, ten antwoord geeft: dat is jammer, want de Godsdienst hoort immers overal in het leven thuis." 
3) Omdat de schrijver onder de motto "Leerkwestie en Repliek" iemand laat zeggen, wat hij nooit heeft kunnen en willen zeggen; valsche aanhalingen doet en de waarheid verkeert in de leugen, zich aantestellen als een vyand, wie het te doen is om te kwetsen, en niet als een vriend, die de waarheid en den vrede liefheeft. ${ }^{9}$

Hierdie openbare verklaring het nie beteken dat Goddefroy nie van plan was om te reageer op Bosman se skrywes nie. Aanvanklik was sy standpunt om net te swyg. Hy het gestel:

"Toon en inhoud van het bitter, hatelijk en persoonlijk geschrif des heeren Bosman, gaven mij dan ook het volste recht om daarop ganselijk niet te antwoorden"10

Op aandrang van "mannen die hun volk kennen en de Ned Hervormde Kerk liefhebben" het hy tog besluit om Bosman van 'n antwoord te bedien. Vir sy antwoord sou hy egter nie van die openbare dagblaaie gebruik maak nie, maar het hy liewer boekvorm verkies. ${ }^{11}$ Dit sou wel openbaar wees in 'n geskrif wat vir iedereen bekombaar sou wees, maar dan met die uitsluitlike bedoeling

"om werklijk belangstellenden in te lichten, en de waarheid aan den dag te brengen, niet om daarover in discussie te treden met ds H S Bosman, tensij deze zick bekeert van den zondigen weg waarop hij zich nu bevindt. ${ }^{12}$

Op 14 Mei 1889 was sy antwoord gereed maar dit het eers 'n jaar later in Mei 1890 verskyn. ${ }^{13}$ Goddefroy het hom eenvoudig nie laat aanjaag nie en hom ook geensins gesteur aan Bosman se skimpe dat hy nie instaat was om te antwoord nie. ${ }^{14}$ Goddefroy se antwoord was 'n redelik lywige brosjure van 135 bladsye waarin hy:

"Meer dan 25 beschuldigingen, behalwe misbruikte aanhalingen (heb ik) moeten weerleggen."15

Op Goddefroy se antwoord wat die titel "De Kerkkwestie niet een Leer - maar een Lewenskwestie" gedra het, het Bosman nooit gereageer nie en die geskryf in die koerant het ook daarna verminder. ${ }^{18}$

Voordat nou nader ingegaan word op die inhoud van die kontrovers is dit nodig om enkele opmerkings te maak oor die twee persone wat by die kontrovers betrokke was.

Herman Stephanus Bosman, wat op 26 Junie 1848 te Victoria-Wes gebore is, het op vierjarige ouderdom saam met sy ouers na Potchefstroom in die Transvaal verhuis, maar gedurende 1862 saam met ds Andrew Murray (jr) van Worcester na die Kaap Kolonie 
teruggekeer met die voorneme om predikant te gaan word. ${ }^{17}$ Bosman ondergaan hier sterk Engelse invloede, sowel kultureel as teologies. Hy word deel van die gesin Murray en sy teologiese insigte word blywend deur Murray beïnvloed. Sy skoolopleiding ontvang hy by $\mathbf{A}$ $\mathrm{N}$ Rowan en sy propodeutiese studie voltooi hy aan die South African College. Teen die einde van 1873 voltooi hy sy teologiese studies aan die kweekskool te Stellenbosch en volg daarna vir ses maande lesings te Edinburg aan die kweekskool van die Skotse Vrye Kerk. Daarna besoek hy vir vier maande die universiteite van Utrecht en Leiden in Nederland; hy besoek ook nog verskillende sendingstigtings en teologiese skole in Duitsland en elders om weer teen Oktober 1875 in Kaapstad terug te wees. Wat hier beklemtoon moet word is die feit dat Bosman baie sterk onder die invloed gekom het van die metodisme wat na 1860 in die Kaapse kerk ingevoer is om die opkomende liberalisme in die Kaapse kerk teen te gaan. ${ }^{18}$

$\mathrm{Na}$ legitimasie het Bosman 'n beroep na die Nederduitsch Hervormde gemeente Pretoria ontvang en besluit om dit aan te neem. ${ }^{19}$ Van die kant van die Nederduitse Gereformeerde Kerk is die beroeping van Bosman geïnterpreteer as ' $n$ ontwaking by die lidmate van die Nederduitsch Hervormde Kerk wat nou

"door beroeping van regtzinnige Predikanten, hunne Kerk te zuiveren van de dwalingen door de Modernen ingevoerd." 20

Bosman se aanvaarding van ' $n$ beroep in die Nederduitsch Hervormde Kerk is gesien as ' $n$ daad van selfopoffering

"ten einde het zuiwer Evangelie aan onkundige en misleide leden der Kerk te brengen. ${ }^{21}$

Daarom moes die broederhand van Ned Cereformeerde kant aan hom gereik word sodat die beweging om "regtzinnige" predikante te beroep aangemoedig sou word

"met het doel om de breuk door de Modernen in die Transvaalsche Kerk veroorzaakt te helen." ${ }^{22}$

Dit het egter nie 'n erkenning van die Nederduitsch Hervormde Kerk ingehou nie. ${ }^{23}$

Besiel met hierdie ideale het Bosman die herderstaf in die Nederduitsch Hervormde Kerk opgeneem. Sy hart was ongetwyfeld by die Nederduitse Gereformeerde Kerk en hy het selfs openlik die opmerking gemaak dat daar baie meer gelowiges in die Nederduitse Gereformeerde as in die Nederduitsch Hervormde Kerk was. ${ }^{24}$ Dit is daarom veelseggend dat hy die man was wat die beweging tot kerkvereniging aan die gang gesit het met 'n beskrywingspunt wat 
hy op die Algemene Kerkvergadering van die Nederduitsch Hervormde Kerk van November 1879 ingedien het naamlik;

"Wat kan er gedaan worden om een vereeniging tot stand te brengen tuschen de Ned Hervormde en de Ned Gereformeerde Kerken in de Transvaal?"25

Marié Joseph Goddefroy ${ }^{26}$ is 'n paar maande na Bosman op 30 Oktober 1848 te Brussels in België gebore. Sy skoolopleiding het hy aan die Waalse Hervormde Weeshuisskool te S'Gravenhage (Den Haag) ontvang om daarna 'n tyd lank onderwys te gee. In 1870 besoek hy die "Christelijke Gymnasium" te Zetten en daarna die Hoëre Burgerskool te ZaltBommel voordat hy op 25 September 1871 met sy teologiese opleiding aan die Universiteit van Utrecht begin. Onder die hooglerare B ter Haar, J J van Oostersee, J I Doedes en Nicolaas Beets het hy kennis gemaak met 'n Bybelse teologie wat supranaturalisties-eties gekleurd was.

In November 1876 het Goddefroy proponentseksamen afgelê en kort daarna ' $n$ beroep aanvaar na die gemeente Lage Zwaluwe in die provinsie Noord-Brabant. Waarop hier klem gelê moet word, is dat Goddefroy van die begin af 'n behoudende teoloog was en juis dit het hom vir sy eerste gemeente aanvaarbaar gemaak. Die Kerkraad van Lage Zwaluwe wat geen teologies liberale of vrysinnige predikant op hulle kansel wou toelaat nie, het eers deur middel van 'n kommissie vasgestel of Goddefroy in die opsig vir hulle aanvaarbaar sou wees, voordat hy beroep is. Vanweë die feit dat al die predikante van die omliggende gemeentes teologies liberaal was en Goddefroy saam met hulle in die ring van Geertruidenburg sitting gehad het, het dit hom van die begin af gedwing om hom duidelik af te grens teenoor die liberales. Dit het daartoe meegewerk dat sy eie teologiese insigte volkome in lyn gekom het met die Bybelsreformatoriese teologie en dat hy ontwikkel het in 'n kampvegter vir die Bybels-reformatoriese geloof.

Nadat Goddefroy tussen 1880 en 1882 die gemeente Ijsselmonde bedien het, het hy die herderstaf opgeneem in die gemeente Achlum Hitzum in die provinsie Friesland. Veral in die kombinasiegemeente het Goddefroy getoon dat hy 'n uiters bekwame teoloog was en 'n vaardige stryder teen die liberale denkrigting. ${ }^{27}$

Die kombinasiegemeente Achlum in Hitzum het, voor Goddefroy se koms daarheen, bekend gestaan as 'n sogenaamde "Liberale" gemeente, waar die predikant en die leidinggewende figure in die gemeente teologies liberaal was. Die oorlewering wil dat Goddefroy as gevolg van ' $n$ vergissing daarheen beroep is. ' $n$ Hewige stryd het gevolg wat vir vyf jaar geduur het, maar waaruit Goddefroy as oorwinnaar gestap het aangesien die mag en invloed van die liberale groep totaal beëindig is en daarna het die gemeente as ' $n$ "regsinnige" gemeente bekend gestaan. 
Goddefroy se teologiese gedagtes kan getipeer word as in lyn met die van prof $\mathrm{P}$ Hoedemaker en sy konfessionele rigting, hoewel Goddefroy self nooit lid was van die rigting of van enige van die ander rigtings wat in die vorige eeu in die Nederlandse Hervormde Kerk gevorm is nie. ${ }^{28}$ Eweneens het sy skerp en besliste afwysing van die teologiese liberalisme nie beteken dat hy hom aan die kant van Kuyper en sy afskeiding van die Hervormde Kerk sou skaar nie. Die belydenis van die kerk was vir hom belangrik en dit moes gehandhaaf word, maar nooit mag dit bo of selfs op gelyke vlak met die heilige Skrif gestel word nie. Sy siening was: ${ }^{29}$

"Geen Christendom zonder Christus, geen Kerk zonder belijdenis; maar ook geen belijdenisschrift of formulier boven of nevens het onbedriegelijke Woord des Heeren."

By sy aanvaarding van die beroep na die Nederduitsch Hervormde Kerk in Transvaal in $\mathbf{1 8 8 7}$ het hy hom volkome vereenselwig met die kerk waarin hy predikant was in Nederland. Verder het daar by hom 'n baie sterk pro-Boerse en skerp anti-Engelse gesindheid bestaan, vandaar dat hy hom volkome kon vereenselwig met sy aangenome volk se ideale en strewe om 'n soewerein onafhanklike volk vry van enige Engelse invloed te bly. ${ }^{30}$

Uit die voorafgaande is dit duidelik dat Bosman en Goddefroy kerklik-teologies en kultureel-polities verskillende agtergronde gehad het en in die kontrovers kom dit ook duidelik na vore dat hulle uiteenlopende standpunte oor die sake gehuldig het. Buitendien het hulle ook nie die hele kerkvereniging uit dieselfde hoek besien nie. Bosman het die kerkvereniging as volkome wettig en daarom bindend vir al die lede van die deelnemende kerke gesien, terwyl Goddefroy daarvan uitgegaan het dat die kerkvereniging ultra vires was en dus sonder bindende krag.

\section{Inhoud van die Kontrovers}

Bosman het met die betiteling van sy reedsgenoemde reeks artikels naamlik "De Leerkwestie" duidelik laat blyk wat hy as die "eigenlijke spil waarom de gehele kerkkwestie draait" gesien het. ${ }^{31}$ In sy openingsparagraaf het hy daarom gestel; ${ }^{32}$

"Er is veel geschreven over de kerkkwestie. Een belangrijker, stichtelijker en nuttiger onderwerp is, dunkt mij, de Leerkwestie. Of is niet een leer der kerk van veel meer waarde dan de naam?"

Die titel wat Goddefroy se antwoord gedra het naamlik "De Kerkkwestie niet een Leer - maar en Lewenskwestie" laat net so duidelik uitkom wat hy as die tersaaklike kwessie beskou het. Dit 
het vir Goddefroy en vir die Hervormde Kerk gegaan om 'n nasionale-lewenskwessie. Hulle het geoordeel dat die kerkvereniging die gevaar van verengelsing op kerklik-kulturele vlak vergroot het, wat weer die staatkundig-politieke onafhanklikheid van die Zuid-Afrikaansche Republiek in gedrang kon bring. Aan so 'n verengelsingsproses wou Goddefroy en die Hervormde Kerk geen deel hê nie, maar die Ned Hervormde Kerk moes juis gehandhaaf word om te dien as 'n bolwerk vir die geestelike onafhanklikheid van die Transvaalse Afrikaner. ${ }^{33}$

Hoewel die direkte aanleiding vir Bosman se koerantskrywers 'n brief, geteken deur 'n sekere Janus was, wat op 24 Desember 1888 in de Volkstem verskyn het, verklaar hy dat hy reeds geruime tyd van oortuiging was dat die kwessie van die "leer" van die kerk ter sprake moes kom. Volgens hom het hy 'n vierledige doel met sy artikels gehad naamlik:

“a. De zuiverheid der leer en de vromigheid des levens onder ons te vevorderen.

b. Ons volk meer bekend te doen worden met den zakelijken inhoud van de leer onzer vaderen en onzer kerk, zooals die uitgedrukt is in de drie formulieren van Enigheid.

c. Aan te toonen hoe en door wie die leer langzaam maar zeker verwaterd en ondermijnd wordt, en

d. Het volk dezer Republiek ernstig op het harte te binden hun heilige roeping en dure verplichting om bij die leer door Gods genade te blijven, en alle dwalingen daartegen strijdende te verwerpen en uit hunne kerken te weren. ${ }^{34}$

Bosman stel dat die hele volk, "een volk in merg en been Calvinistisch en Dordtschgesind is," Daarom wil hy die kerkkwessie nie 'n kerkgenootskaplike aangeleentheid maak nie, maar vra hy van die hele volk "ernstig en welwillend hun oor, hart en geweten." ${ }^{\prime 36}$ Dan neem hij stelling in agter Artikel 20 van die grondwet van die Zuid-Afrikaansche Republiek wat soos volg lui: ${ }^{37}$

"Het volk wil zijn Nederduitsch Hervormde Godsdienstleer, zooals deze in de jaren 1618 en 1619 door de Synode te Dordrecht is vastgesteld, in hare grondbeginselen blijven behouden."

Uit die voorafgaande sou verwag kon word dat Bosman uitvoerig sou ingaan op minstens die belangrikste leerstukke van die kerk soos te Dordt vasgestel. Trouens dit sou die enigste doeltreffende metode wees om sy "voortreflijk vierledig doel" 38 te kan bereik. As Bosman hom daaraan sou gehou het, so verklaar Goddefroy dan sou hy hom as bondgenoot kon reken: 
"Ieder welmeenende poging tot handhaving van de zuivere leer en het Christendom naar de Schriften, kan tevoren rekenen op mijne dankbaarheid." ${ }^{39}$

As Bosman egter verklaar dat hy in sy skrywes sou aantoon:

"In hoeverre aan dit artikel (artikel 20-) voldoen word door personen, sekten en genootschappen, 0 a door Janus, zijn Ds en de afgesheiden "Hervormde Kerk"40

dan kom sy werklike doelstelling met sy artikelreeks na vore. Gaandeweg het dit ook duidelik geword dat hy nie van plan was om enige van die leerstukke wat dan ter sake sou wees, sou behandel nie, maar dat hy alleen maar 'n aantal beskuldigings en bewerings, wat hy ook nie behoorlik kon substansieer nie, teen die Hervormde Kerk en sy predikant ds M J Goddefroy opgewerp het.

Heeltemaal tereg merk Goddefroy daarom in sy antwoord op:41

"Wat heeltemaal vreemd en jammer mag heeten is dat in al die lange stukken des heeren $B$, niet een enkele fundamenteel leerstuk der Ned Hervormde Kerk behandel wordt. Nóch de leer der Praedestinatie, dat Cor Ecclesiae, ook aan den heer B zoo goed bekend; nóch de leer der Heilige Drievuldigheid; nóch de leer der Sacramenten! Niets letterlijk niets van dat alles, wordt door den heer Bosman ook maar oppervlakkig behandeld."

Goddefroy betreur dit dan dat Bosman soveel klem lê op die "leer" om van daaruit allerlei beskuldigings te maak sonder om ooit:

"aandagtig en eerbiedig een dier kenmerkende leerstukken onderhanden te nemen." ${ }^{42}$

Bosman het ' $n$ hele aantal ernstige beskuldigings teen die Hervormde Kerk en sy predikant ingebring.

Een van die eerste beskuldigings wat Bosman gemaak het, was om vanaf sy eerste artikel van die Hervormde Kerk as "de afgeskeiden Hervormde Kerk" te praat. Verskonend voeg hy daaraan toe "men duide mij dese benaming met euvel; bekend zooals ik ben met de geheele toedracht der zaak, kan ik die kerk niet anders noem." ${ }^{\prime 43}$

Uit hierdie verskonende opmerking van Bosman is dit al duidelik dat hy self besef het dat die benaming kwetsend was. Tog het hy voortgegaan om telkens met klem te verwys na die afgeskeie en "nuwe" Hervormde Kerk. Daarmee het hy die Hervormde Kerk dus as 'n skeurkerk bestempel. Hy voer egter geen bewyse aan vir sy bewering nie. Goddefroy se antwoord is daarom eenvoudig:

“Op welke redelijke gronden Ds B gedurig in zijn courant geschrijf de Oude Hervormde Kerk, als afgescheiden Her- 
vormde Kerk voorstelt, word na al die gezegde niet zeer duidelijk. Al waren in deze Republiek ook maar drie lidmaten der Ned Hervormde Kerk blijden staan bij de Belijdenis, de Statuten en den Naam van de Oude Kerk hunner vaderen, dan nog zou het alleen als eene hatelijkheid zijn aan te merken als men spreekt van 'Afgescheiden kerk'."14

Dat Goddefroy volkome korrek was in sy siening, dat diegene wat by die Hervormde Kerk gebly het en nie met die vereniging meegegaan het nie, historiese voortsetting was van die Ned Hervormde Kerk, sou deur die hofuitsprake van 1894 duidelik bewys word. ${ }^{45}$

' $n$ Tweede beskuldiging van Bosman teen die Ned Hervormde Kerk, was die ou en reeds dikwels herhaalde beskuldiging dat die Hervormde Kerk liberaal sou wees wat die leer aanbetref.

Dit is egter nie duidelik wat Bosman onder "liberaal" verstaan nie. Hy gee geen omskrywing of definisie van wat dit vir hom inhou nie. Hy maak wel die bewering en voer dan sekere sake aan wat vir hom as bewyse geld dat die Hervormde Kerk liberaal sou wees.

1. In die eerste plek koppel hy dit aan die naam Hervormd. Hy stel. ${ }^{46}$

"dat zoodra men den naam Hervormd alleen aanneemt, de deur geopend wordt voor afwijkingen in de leer en de praktijk der vaderen."

Hierby aansluitend beweer hy dat die Hervormde Kerk die woord Gereformeerd verag. Bosman het egter ietwat in 'n verleentheid verkeer oor die woorde Hervormd en Gereformeerd. Uit die volgende aanhaling uit sy artikels word dit duidelik:

"Artikel 20 van de Grondwet spreekt van de Hervormde godsdiensleer. In het voorbijgaan zij opgemerkt dat deze benaming onjuist is. Immers de leer der Kerk is Gereformeerd, slechts haar naam Hervormd; en daarom passen die twee woorden zoo goed bij elkander." ${ }^{\prime 47}$

Hoewel dit reeds lank tevore duidelik geblyk het dat Bosman in werklikheid teen die woord "Hervormd" gekant was, kon hy in 1889 beswaarlik nog die standpunt handhaaf, aangesien die kerk waartoe hy behoort het die naam "Ned Hervormd of Gereformeerd" gedra het.

Aangesien hy bewus was van Bosman se vroeëre eienaardige optrede ten opsigte van die naam van die kerk buit Goddefroy Bosman se verleentheid uit as hy sê:

"Maar waarom passen nu die twee woorden zoo goed bij elkander? Omdat ze beiden hetzelfde beteekenen en Hervormd 
$=$ Gereformeerd, Gereformeerd = Hervormd is? Zodoende

beteken: "de Ned Hervormde of Gereformeerde Kerk"48

Met ' $n$ beroep op Wilhelmus a'Brakel toon Goddefroy aan dat die bewering

"dat het aanneemen van een 'naam' de deur opent voor afwijkingen in de leer,"

werklik nie ernstig opgeneem kan word nie..$^{49}$

Wat Bosman se bewering aanbetref dat die Hervormde Kerk die woord "Gereformeerd" verag, verklaar Goddefroy dat dit nog een van die onaangename onjuisthede is waarvoor Bosman geen enkele bewys kon aanvoer nie. Hy stel: ${ }^{50}$

"Dat woord uit den tijd toen men onder die Hervormers sprak van de 'ware gereformeerde Religie'; of van de 'gereformeerde Kerken dezer landen' is ons heilig en dierbaar en roept ons een verleden voor den geest toen men het gebruikte in de echt Paulinische beteekenis: wordt geformeerd in den geest uws gemoeds."

Maar as Bosman dan die bewering kan maak dat die woord Hervormd ' $n$ byklank het, dan bring Goddefroy dit onder sy aandag dat vir die Hervormde mense in Transvaal die woord "Gereformeerd" ook 'n byklank kan hê.

"Beweert iemand nu in navolging van ds Lion Cachet ... dat Hervormd en Gereformeerd ongeveer tot elkander staan als:, een baatje en een bô-baatje; dan antwoorden onze Hervormde menschen eveneens in de taal des volks: ja maar wij willen allemans baatje lang niet dragen; rooibaatjes zijn bij ons niet in trek." ${ }^{\prime 51}$

Die twis rondom die woorde Hervormd en Gereformeerd, die onsalige erfenis van ds $\mathrm{F}$ Lion Cachet, wat weer deur Bosman en ander na vore gehaal is, is deur Goddefroy beskou as sinneloos.

"Maar wat wij vinden om af te bidden, is dat stelselmatig repristineeren, waardoor sommige meenen zoo al niet Gode dan toch het volk een dienst te bewijzen; dat knutselen en knoeien met namen en vanen, dierbaar door historische herhinneringen, en nu dienstbaar voor politieke doeleinden. Waarlijk den treurigen toestand waarin menige Kerk zich bevindt, behoeft niet gezocht te worden in uitwendige omstandigheden, ook niet in een Naam . . ."52 
2. 'n Tweede saak waaruit die Hervormde Kerk se liberalisme ten opsigte van kerkleer, volgens Bosman, sou blyk, is die feit dat die Hervormde Kerk sou afgewyk het van die Reformatoriese leer deurdat die belydenisskrifte dan nou nie in die Hervormde Kerk tot hulle reg sou kom nie. In sy poging om bewyse aan te voer, kom dit egter aan die lig dat daar by Bosman oor hierdie hele aangeleentheid geen duidelikheid was nie. Die begrip wat hy openbaar ten opsigte van die werklike en juiste verhouding tussen Skrif, belydenisskrif en die predikant se verpligting om, volgens die proponentsondertekeningsformules, die belydenisskrifte te handhaaf, is redelik verward. ${ }^{53}$

Die gevolg daarvan was dat waar Bosman aanvanklik die aanklaer was wat die Hervormde Kerk en sy predikant van ' $n$ "mengelmoes van on-Dordtsche en on-Gereformeerden beginselen" beskuldig het. hyself deur Goddefroy in die beskuldigde bank geplaas is onder aanklagte van Rooms, on-Dordts, on-Gereformeerde en selfs on-Christelik.

Voortdurend het Bosman verklaar dat dit vir hom gegaan het om die suiwere leer. Die vraag is egter wat Bosman as die suiwere leer beskou het, omdat hy hom nogal teenstrydig daaroor uitgespreek het. Onder andere verklaar hy dat die suiwere leer is "de leer der vaderen omdat die ook is de leer des Bybels. ${ }^{.54}$

Goddefroy se reaksie hierop is skerp en verdoemend. Hy sien dit as skromelike begripsverwarring waar menslike skriftuur gelykgestel word met Gods Woord. Hy wys daarop dat Artikel 7 van die Nederlandse Geloofsbelydenis nie toelaat dat enige menslike geskrif selfs vergelyk word met die Heilige Skrif wat nog te sê gelyk gestel word daarmee. En dit is presies wat Bosman se stelling ingehou het naamlik.

"de leer der vaderen is de leer des Bybels."

Daarom is die siening van Bosman nie alleen anti-Gereformeerd nie, maar suiwer Rooms. Tereg wys Goddefroy daarop: ${ }^{\mathbf{5 5}}$

"Dit is een hoog-ernstige dwaling, en een aanranding van de hoogheiligheid van het woord der Openbaring in de Schriften des $\mathrm{O}$ en des $\mathrm{N}$ Testamentes."

Ook in ' $n$ ander stelling van Bosman blyk dat daar by hom 'n vreemde Skrifbeskouing aanwesig was.

“Duidelijker gesproken - ik versta de $\mathrm{H}$ Schrift in den zin waarin de gezuiverde kerk aller eeuwen die verstond, en dus overeenkomstig de 3 Formulieren van Eenigheid."

Tereg vra Goddefroy op hierdie stelling: 
"Maar hoe heb ik het nu met ds B? Moet nu het licht der Formulieren de H Schriften opklaren?"

Goddefroy toon daarna dan duidelik aan dat so 'n Skrifbeskouing ongetwyfeld terugvoer na Rome. Oor die probleem van watter die gesuiwerde kerk sou wees gaan Goddefroy in sy antwoord ook nader in, maar dit word hier nie aangesny nie.

Goddefroy verklaar dan hoe die Kerkhervormers wel die suiwere leer gesien het: ${ }^{57}$

"de suivere leer is nooit of te nimmer bij de Hervormers; de leer hunner vaderen, of van de Concilies, maar altijd en alleen wat de Heilige Schriften leeren."

Hiervoor voer hy verskillende bewyse aan onder andere artikel 5 en 7 van die Nederlandse Geloofsbelydenis.

Dit is wel waar dat Bosman ook verklaar het dat, hy geensins die Belydenisskrifte bo of naas Gods Woord plaas nie. ${ }^{58}$ In die lig van sy voorafgaande stelling is dit egter duidelik dat daar by hom ernstige begripsverwarring ten opsigte van die saak bestaan het.

'n Ander opsig waarin die Hervormde Kerk volgens Bosman van die suiwere leer afgewyk het, kom na vore by die proponentsondertekeningsformule waar die Hervormde ondertekeningsformule die betekenislose "quatenus" (in soverre) sou vereis het in plaas van die hartlike "quia" (omdat) soos dit dan in die verenigde kerk die geval sou wees. ${ }^{59}$ Volgens hom sou die Hervormde Kerk en ds Goddefroy met die vereistes van die verwaterde "quatenus," 'n deel van die volk (wat dus aan die Hervormde Kerk behoort het) op 'n bedekte wyse op ' $n$ ander spoor as die Dordtse oorgebring het. So word leervryheid in die kerk ingesmokkel en word inderdaad die ondergang van die Christelike kerk beoog.

Dit is natuurlik ' $n$ baie ernstige beskuldiging teen die Hervormde Kerk wat, indien dit vals sou wees, as beledigend en lasterlik beskou kan word.

Bosman voer ' $n$ hele aantal argumente aan wat hy as bewyse sien van die verderflike voortgang van leervryheid in die Hervormde Kerk as gevolg van die loslaat van die quia in die ondertekeningsformule. Argumente wat hy noem is die volgende:

a. Dit het die Hervormde Kerk op 'n geheel ander standpunt geplaas, wat die handhawing van die leer aanbetref, as enige van die ander Hollandse kerke in Suid-Afrika. ${ }^{60}$

b. Daar word by die Hervormde Kerk "eene lossigheid op het gebied van a. leer, b. dienst, c. tucht en d. leven" gevind. ${ }^{61}$

Goddefroy gaan in op die bewering van Bosman dat hy die Hervormde kerk die quatenus vereis word en sê:: 
"Ook hierin spreekt ds Bosman geheel bezijden de waarheid, aangesien het voor mij ten allen tijde en ook nu nog een ongerijmdheid is bij de ondertekening van de Formulieren eener Kerk te spreken van, of te denken aan een quatenus, waardoor de geheele ondertekening willekeurig wordt, en gelijk staat met niet ondertekening."

Verder toon Goddefroy aan dat daar geen wesenlike verskil is tussen die ondertekeningsformules van die verskillende Hollands Afrikaanse kerke nie en dat daar ook geen leerverskille tussen die kerke bestaan of ooit bestaan het nie. Selfs nie die nuwe verenigde kerk het die Dordtse ondertekeningsformule onveranderd ingevoer nie, trouens, dit was slegs'n gedeeltelike invoering. Goddefroy toon dan aan hoedat Bosman klaarblyklik in enige stuk ' $n$ optelsom maak van die aantal kere wat die woord "leer" daarin voorkom en dit bepaal dan hoe regsinnig of onregsinnig so 'n stuk dan sou wees. In hierdie verband haal Goddefroy die ondertekeningsformule, soos deur Calvyn goedgekeur, volledig aan waaruit blyk dat die woord leer selfs nie een keer gebruik word nie. Daarby maak hy dan die opmerking: ${ }^{63}$

'Hij die zorgvuldig optelt hoeveel maal het woordje 'leer' in onze Formulieren voorkomt, moet zich zeker wel uitermate ergeren aan Johannes Calvinus."

In die hele aangeleentheid rondom die ondertekeningsformule is daar twee aspekte wat deur Goddefroy na vore gebring word, waarop die aandag gevestig moet word.

Ten eerste vra hy hoe dit moontlik is dat Bosman "zulke dwaze en onbewesene" beskuldigings kan maak ten opsigte van die begrippe "quia" en "quatenus" by die Hervormde Kerk. Dan stel hy ietwat spottend die vraag: ${ }^{64}$

"Toch niet uit het particuliere gesprek dat hij eenmaal met mij gehad heeft en waarop in zijn verdachtmakend courantgeschrijf word gezinspeeld? In dat geval is hij eenigszins misschien te excuseren omdat ik niet goed Engelsch en hij niet goed Hollandsch spreekt ...."

Hier blyk eenersyds die verskillende politieke gesindhede wat by die twee bestaan het, terwyl andersyds daar vir Goddefroy ook die dieperliggende probleem aanwesig was dat Bosman geen duidelike begrip gehad het van die teologiese aspekte wat op die spel was nie.

Ten tweede toon Goddefroy duidelik aan dat Bosman nie die Gereformeerde beginsel handhaaf om die Hervormde Kerk se ondertekeningsformule aan die enigste onfeilbare reël, naamlik Gods Woord, te toets nie. Hy stel dan: 
"Ongelukkig is ds B niet zuiwer Gereformeerd genoeg om zich op dit echt Christelijk en Protestantsch standpunt te kunnen plaatsen, en beroept zich tegen Artikel 7 onzer Geloofsbelijdenis in, op die groote menigte, de Oudheid en de successie van tijden! De geest en aanleg van ons volk, de rechtsinnige vaderen van 1618; met en benewens 150 "Hollandsche Predikanten van Z-Afrika worden opgeroepen ons van dwaling te overtuigen. Zóó kan een mensch Anti-Gereformeerd zijn, zonder het zelf te weten. Ziet dit maakt een pennestrijd met zoo iemand werkelijk moeilijk en zwaar."65

Die hele poging van Bosman om te bewys dat die Hervormde Kerk en ds Goddefroy leervryheid voorgestaan het, is deur Goddefroy as 'n on-Christelike, kwetsende belastering en verdagmaking gesien omdat dit geheel en al "zonder eenigen schijn van bewijs" was. Immers, Goddefroy kon met reg verklaar. ${ }^{66}$

"Terwijl ik steeds met geheel mijn hart de gevaarlijke beginselen van het modernsime en liberalisme opentlijk heb weerstaan."

Ten opsigte van die eenheid van die kerk het daar ook verskil van mening bestaan tussen Goddefroy aan die een kant en Bosman en die verenigde kerk aan die anderkant. Van verenigde kerk kant is Johannes 17:21 so uitgelê dat dit kerklike eenheid in organisatoriese sin sou beteken. Goddefroy stel hierteenoor:

"Maar wij zijn zoo vry in deze van mening te verschillen, en achten de eenheid waarvan hier sprake is voor den nauwlettenden Bijbellezer voldoende toegelicht door het: 'gelijk als wij' waarmede toch nimmer een uitwendige eenheid kan bedoeld sijn. De eenheid tusschen den zoon en den Vader die in de Hemelen is, sal toch wel nooit met het uiterlijke in verband gebracht kunnen worden." ${ }^{\prime \prime 7}$

Uiteindelik verklaar Goddefroy dat van die vierledige doel van Bosman, wat op sigself geneem voortreflik was, niks tereg gekom het nie. Eenheid en versoening het dit nie bewerk nie, maar dit het die bitterheid en skeuring eerder laat toeneem.

\section{Konklusie}

As die vraag nou aan die orde gestel word: Waar lê die wortels van die sondige verskeurdheid in die kontrovers Bosman/Goddefroy?" dan moet in die lig van die voorafgaande, die volgende sake oorweeg word. 
1. Dit is duidelik dat Bosman en Goddefroy se uitgangspunte ten opsigte van die hele aangeleentheid verskillend was. Bosman het daarvan uitgegaan dat die kerkvereniging volkome wettig was en daarom het hy diegene, wat die Hervormde Kerk wou handhaaf, as skeurmakers bestempel. Goddefroy was daarvan oortuig en hy het dit ook aangetoon dat die hele kerkvereniging ultra vires was en daarom van nul en gener waarde. Die hofuitspraak van 1894 , toe die hele aangeleentheid noukeurig deur die Hooggeregshof uitgepluis is, het bewys dat Goddefroy reg was.

2. Bosman se poging om aan te toon dat die kerkkwessie ' $n$ leerkwessie was het nie geslaag nie. Hy kon nie aantoon dat die Hervormde Kerk in enige opsig van enige van die kenmerkende Gereformeerde leerstukke afgewyk het nie. Op sy beskuldigings van leervryheid het Goddefroy afdoende geantwoord. In die lig hiervan kan sy beskuldiging van liberalisme teenoor die Hervormde Kerk en ds Goddefroy, as vals en daarom beledigend en lasterlik beskou word.

3. Word die kwaliteit van die argumente van weerskante teen mekaar opgeweeg is dit duidelik dat Goddefroy saaklik bly en noukeuriger formuleer. Bosman se argumente, daarenteen, is nie altyd duidelik nie en onteenseglik het ernstige begripsverwarring by hom bestaan. Hy was eerder daarop uit om op 'n verdagmakende wyse Goddefroy en die ander Hervormde kerkleiers se aansien af te breek en wantroue te skep en die lidmate sodoende van hulle te vervreem. Met sy wyse van skrywe sou hy Goddefroy seker nooit kon wen nie.

4. Bosman wat die groot yweraar vir kerkvereniging was, het met sy reeks artikels en ander koerantgeskryf nie 'n blyk daarvan gegee dat hy so besiel was met die ideaal van kerkvereniging dat hy sou aanhou probeer om versoenend op te tree nie. As lid en verteenwoordiger van die verenigde kerk het die onus op hom gerus om diegene wat nie wou verenig nie, indien moontlik, nader te trek en nie te beledig nie. Dit doen hy egter nie en daarom is sy optrede nie kerkverenigend nie maar eerder kerkskeurend. Hieruit kan die afleiding gemaak word dat dit nooit werklik vir Bosman gegaan het om 'n vereniging tussen die Ned Hervormde en Ned Gereformeerde Kerke te bewerk nie, maar eerder om die Ned Hervormde Kerk dood te kry.

1 Hoewel die Gereformeerde Kerk ook uitgenooi was om oor kerkvereniging te onderhandel, het hulle nooit meegedoen nie. Vergelyk J P Jooste, Die Geskiedenis van die Gereformeerde Kerk in Suid-Afrika 1859-1959, Potchefstroom 1959, bladsy 194 e.v.

2 Die hele kwessie van kerkvereniging is deurentyd slegs op die amptelike vergaderings van die twee kerke bespreek, terwyl die saak nooit aan die gemeentes vir goedkeuring voorgelê is nie. Vergelyk S P Engelbrecht, Geskiedenis van die 
Nederduitsch Hervormde Kerk van Afrika, Kaapstad-Pretoria, Derde uitgawe, bladsy 281 e.v.

3 Die Konsulentsgemeente van Pretoria (Witfontein) het in die geheel geweier om te verenig, terwyl van oral in die ZAR lidmate uit verskeie gemeentes van die Nederduitsch Hervormde Kerk, wat nie met die vereniging wou meegaan nie, hulle hierby aangesluit het. Vergelyk S P Engelbrecht, $a w$, bladsy 302 e.v.

4 Vergelyk vir sommige van die redes S P Engelbrecht, $a$ w, bladsy 327 en G D Scholtz, Die Geskiedenis van die Nederduitsch Heroormde of Gereformeerde Kerk van Suid-Afrika 1885 1910, Kaapstad-Pretoria, s j bladsy 74 e.v.

5 Hier kan gedink word aan diegene wat onder leiding van die ProkurasieKommissie uit die verenigde kerk uitgetree het, om weer in 1894 tot die Nederduitsch Hervormde Kerk toe te tree. S P Engelbrecht, $a w$, bladsy 327 e.v.

6 S P Engelbrecht, $a w$, bladsy 320.

7 Die korrespondensie Joubert-Bosman het ook later in brosjurevorm verskyn onder die titel: Correspondentie en Bijbehorende stukken. Tusschen ds HS Bosman en C J Joubert, Pretoria 1890.

8 M J Goddefroy, De Kerkkwestie niet een Leer- maar een Levenskwestie, Tweede Druk, 's Gravenhage 1890, bladsy 8.

9 M J Goddefroy, $a w$, bladsy 125-126.

$10 \mathrm{M} J$ Goddefroy, $a w$, bladsy $v$.

$11 \mathrm{M} J$ Goddefroy, $a w$, bladsy v.

$12 \mathrm{M} J$ Goddefroy, $a$ w, bladsy 126 . Uit bogenoemde aanhalings is dit duidelik dat Goddefroy hoegenaamd geen behae geskep het in die hele twisgeskryf nie.

13 Die vertraging van die uitgawe het Goddefroy so verklaar: "Werkelijk heeft gewichtiger arbeid mij genoodzaakt de uitgave van de hier volgende bladzijden, tot heden, - Mei 1890 - uit te stellen. Jammer voor degenen die zo brandende waren van verlangen. Gelukkig was uitstel geen afstel; terwyl tevens een goede gelegenheid werd aangeboden tot oefening in geduld en lijdzaamheid." Vergelyk $M \mathrm{~J}$ Goddefroy, $a w$, bladsy vi.

14 Hierop het Bosman in die voorwoord van die tweede uitgawe van sy $D e$ Leerkwestie, gesinspeel.

$15 \mathrm{M}$ J Goddefroy, $a w$, bladsy 126 .

16 Goddefroy se antwoorde was blykbaar afdoende en "so duidelik. . . dat 'n repliek daarop baie moeilik, indien nie onmoontlik was nie." A D Pont, Ds M J Goddefroy, 1848-1920. ' $n$ Skets van sy lewe en betekenis, artikel in Nederduitsch Hervormde Gemeente Bronkhorstspruit 1869-1969, Krugersdorp 1969, bladsy 158.

17 Vir meer besonderhede oor Bosman sien Amy Bosman, 'n Dankbare terugblik, Pretoria 1960, en F G M du Toit, Herman Stephanus Bosman, artikel in SuidAfrikaanse Biografiese Woordeboek, Kaapstad 1968, Deel 1, bladsy 107.

18 Vergelyk in hierdie verband S P Engelbrecht, Thomas Francois Burgers, Pretoria 1933 , bladsy $41 \mathrm{vv}$.

19 Terselfdertyd is nog 'n Stellenbosche kwekeling, DP Ackerman, na die Nederduitsch Hervormde Gemeente Wakkerstroom beroep. SP Engelbrecht, Geskiedenis, bladsy 247.

20 Dit is soos die Natalse Sinode van die Ned Gereformeerde Kerk die saak gestel het. Aangehaal by S P Engelbrecht, $a w$, bladsy 248 .

21 S P Engelbrecht, $a w$, bladsy 247.

22 S P Engelbrecht, $a w$, bladsy 248. Die bedoeling van die Natalse Sinode was skynbaar dat meer Stellenbosche kwekelinge beroep moes word, sodat die Nederlandse predikante in die Nederduitsch Hervormde Kerk weldra in die minderheid sou wees en 'n kerkvereniging dan makliker sou deurgaan. As na die predikante getalle in 1885, met die kerkvereniging gekyk word, dan kom dit voor asof hulle plan geslaag het. Op daardie stadium was nog slegs di $\mathrm{N} \mathrm{J}$ van Warmelo en G W Smits uit Nederland, terwyl die ander vier diensdoende predikante almal van Stellenbosch afkomstig was.

23 Daar is by die standpunt gebly dat die Ned Hervormde Kerk nie erken kan word nie, omdat leervryheid toegelaat word en daar sogenaamde "moderne" predikante diens gedoen het. S P Engelbrecht, $a w$, bladsy 248 .

24 S P Engelbrecht, $a w$, bladsy 281 .

25 S P Engelbrecht, $a w$, bladsy 281.

26 Vir meer besonderhede oor Goddefroy vergelyk A D Pont, $a w$, en S J Botha, $D s$ 
Marie Joseph Goddefroy, artikel in die Almanak van die Nederduitsch Hervormde Kerk 1977, bladsy 19-23.

$27 \mathrm{~S} J$ Botha, $a$ w, bladsy 83.

$28 \mathrm{~S} \mathrm{~J}$ Botha, $a w$, bladsy 23 . Vergelyk ook S P Engelbrecht, Neo-Calvinisme Ontwikkeling en Afwyking, Pretoria-Kaapstad 1945, bladsy 53.

29 Aangehaal by S P Engelbrecht, Geskiedenis, bladsy 317.

$30 \mathrm{~S} J$ Botha, $a w$, bladsy 23.

31 H S Bosman, De Leerkwestie, tweede uitgawe, Pretoria 1889, bladsy 5.

32 H S Bosman, a $w$, bladsy 5 .

33 A D Pont, $a w$, bladsy 143.

34 H S Bosman, $a w$, bladsy 5 .

35 H S Bosman, $a w$, bladsy 5 .

36 H S Bosman, $a w$, bladsy 5 .

37 H S Bosman, $a w$, bladsy 6 .

38 Goddefroy merk op dat tenspyte van die voortreflik vierledige doel, Bosman tog "verloopt in persoonlijkheden - en dus werkelijk zijn onderwerp niet naar eisch behandelt ..." M J Goddefroy, $a$ w, bladsy 8.

39 M J Goddefroy, $a w$, bladsy iv.

40 H S Bosman, $a$ w, bladsy 6. Hierdie opmerking van Bosman, om die Hervormde Kerk met 'n sekte te vergelyk, moet as van die "hatelijkheden en verdachtmakingen" en "onheilige en onteedere manier van strijdvoeren" gesien word, waarteen Goddefroy ernstig beswaar gehad het. M J Goddefroy, $a$ w, bladsy iv.

$41 \mathrm{M} J$ Goddefroy, $a w$, bladsy 8.

42 M J Goddefroy, $a w$, bladsy 8.

43 H S Bosman, $a w$, bladsy 6 .

44 M J Goddefroy, $a$ w, bladsy 43.

45 Vergelyk byvoorbeeld die uitspraak van die Hooggeregshof in die Trichardtsfontein kerksaak. S J Botha, Ontleding van die Kerksaak van Trichardtsfontein 1893, artikel in die Hervormde Teologiese Studies, sewentiende jaargang, aflewering 1, Julie 1961, bladsy 1-18.

46 H S Bosman, $a w$, bladsy 6.

47 H S Bosman, $a w$, bladsy 6.

$48 \mathrm{M}$ J Goddefroy, $a w$, bladsy 79.

49 M J Goddefroy, $a$ w, bladsy 78.

50 M J Goddefroy, $a w$, bladsy 79-80.

$51 \mathrm{M} J$ Goddefroy, $a w$, bladsy 44.

$52 \mathrm{M}$ J Goddefroy, $a w$, bladsy 80 .

53 Vergelyk in hierdie verband A D Pont, Heilige Skrif, Belydenis en Kerklike Orde, artikel in die Van der Hoff-jaarblad 1973, bladsy 25-28.

54 H S Bosman, $a w$, bladsy 8.

$55 \mathrm{M}$ J Goddefroy, $a w$, bladsy 13 .

56 H S Bosman, a $w$, bladsy 9.

$57 \mathrm{M}$ J Goddefroy, $a w$, bladsy 11 .

58 H S Bosman, a $w$, bladsy 9.

59 H S Bosman, $a w$, bladsy 9 en 10 .

60 H S Bosman, $a w$, bladsy 10 .

$61 \mathrm{H} \mathrm{S}$ Bosman, a $w$, bladsy 11 .

62 M J Goddefroy, $a w$, bladsy 19.

63 M J Goddefroy, $a w$, bladsy 22.

$64 \mathrm{M}$ J Goddefroy, $a w$, bladsy 19.

$65 \mathrm{M}$ J Goddefroy, $a w$, bladsy 20.

66 M J Goddefroy, $a w$, bladsy 25.

67 M J Goddefroy, $a w$, bladsy 67 . 